\section{STRENGTH, WATER ABSORPTION AND THERMAL COMFORT OF MORTAR BRICKS CONTAINING CRUSHED CERAMIC WASTE}

Noorli Ismaila, Norhafizah Salleha, Noor Faezah Mohd Yusofa, Zalipah Jamellodina, Mohd Faizal Mohd Jaafarb

aFaculty of Civil Engineering and Environmental, Universiti Tun Hussein Onn Malaysia (UTHM), Johor, Malaysia

bFaculty of Civil Engineering and Earth Resources, Universiti Malaysia Pahang, Pahang, Malaysia
Article history

Received

19 April 2017

Received in revised form

3 July 2017

Accepted

10 September 2017

*Corresponding author noorli@uthm.edu.my

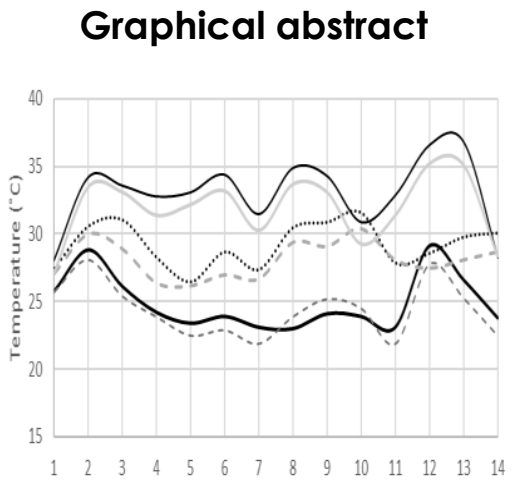

\begin{abstract}
This present study investigated the crushed ceramic waste utilisation as sand replacement in solid mortar bricks. The percentage of crushed ceramic waste used were 0\% (CWO), 10\% (CW10), 20\% (CW20) and 30\% (CW30) from the total weight of sand. The dimension prescribed of mortar bricks are $215 \mathrm{~mm} \times 102.5 \mathrm{~mm} \times 65 \mathrm{~mm}$ as followed accordance to MS 2281:2010 and BS EN 771-1:2011+A1:2015. Four (4) tests were conducted on mortar bricks namely crushing strength, water absorption, compressive strength of masonry units and thermal comfort. The incorporation of ceramic waste in all designated mortar bricks showed the increment of crushing strength between $23 \%$ and $46 \%$ at 28 days of curing and decrement water absorption between $34 \%$ and $44 \%$ was recorded corresponding to control mortar bricks. The prism test of masonry units consists of mortar bricks containing ceramic waste indicated the high increment of compressive strength at about $200 \%$ as compared to mortar brick without ceramic waste. The thermal comfort test of ceramic mortar bricks were also showed the good insulation with low interior temperature. Therefore, the ceramic waste can be utilised as a material replacement to fine aggregate in mortar brick productions due to significant outcomes performed.
\end{abstract}

Keywords: Ceramic bricks, crushing strength, water absorption, thermal comfort

\begin{abstract}
Abstrak
Kajian ini dijalankan untuk mengkaji penggunaan buangan seramik yang dihancurkan sebagai menggantikan pasir di dalam batu-bata mortar. Peratus bahan hancur buangan seramik yang digunakan ialah 0\% (CWO), 10\% (CW10), 20\% (CW20) dan 30\% (CW30) daripada jumlah berat pasir. Dimensi saiz batu-bata mortar yang digunakan ialah $215 \mathrm{~mm} \times 102.5 \mathrm{~mm} \times 65 \mathrm{~mm}$ seperti yang dinyatakan di dalam MS 2281:2010 dan BS EN 771-1:2011+Al:2015. Empat (4) ujian telah dijalankan ke atas batu-bata mortar iaitu kekuatan hancur, penyerapan air, kekuatan mampatan untuk unit masonri dan keselesaan terma. Penggunaan bahan buangan seramik di dalam semua batu-bata mortar menunjukkan kenaikan kekuatan hancur di antara $23 \%$ dan $46 \%$ pada hari pengawetan ke 28 dan penurunan penyerapan air di antara $34 \%$ dan $44 \%$ telah direkodkan berbanding dengan batu-bata mortar kawalan. Untuk ujian prisma unit masonri yang terdiri dari batu-bata mortar mengandungi bahan buangan seramik mencatatkan kenaikan kekuatan mampatan setinggi $200 \%$ jika dibandingkan dengan batu-bata mortar kawalan. Keselesaan terma bagi batu-bata mortar yang mengandungi bahan buangan seramik menunjukkan penebat yang baik dengan suhu dalaman yang rendah. Oleh itu, keputusan yang ditunjukkan dalam kajian ini, menyimpulkan bahan buangan seramik boleh digunakan sebagai bahan penggantian kepada batu halus di dalam pengeluaran batu-bata mortar.

Kata kunci: Buangan seramik, kekuatan hancur, penyerapan air, keselesaan terma
\end{abstract}




\subsection{INTRODUCTION}

Ceramic waste or also known as ceramic dust was classified as waste generated from the clay production such as earthenware, stoneware, sanitary ware, porcelain ware, ceramic sludge and from electrical insulator industrial due to poor quality as rejected wares (Amin et al. 2016 [1]). This accumulation of ceramics waste increased the demand of landfilled disposal. As the alternatives to promote the green environment in order to address the problem of landfilled disposal, ceramic waste had been introduced as the potential additive in enhancing the brick properties. Generally, the usage of ceramic waste was huge used in replacing partially the coarse and fine aggregates in clay bricks (Alonso et al. 2012 [2]; Nirmala and Viruthagiri 2015 [3]; Tereza et al. 2015 [4]; Ali et al. 2016 [5]; Silva et al. 2017 [6]). The inclusion of ceramic waste contents in clay brick productions exhibited the remarkable value of compressive strength and lowest water absorption corresponding to control clay bricks without ceramic waste.

However, limited studies were disclosed in replacing the ceramic waste as fine aggregate in mortar bricks (Jiménez et al. 2013 [7]; Fernando et al. 2017 [8]); Haiying et al. 2011 [9]), therefore the investigation on influence of ceramic waste addition in mortar bricks to their mechanical and physical properties was performed by conducting the laboratory tests as accordance to MS 327: Part 31997 [10] and ASTM C1314-16 [11]. Prior to testing, the specimens of mortar bricks were prepared with size of $215 \mathrm{~mm} \times 102.5 \mathrm{~mm} \times 65 \mathrm{~mm}$ that conforming in MS 2281:2010 [12] and BS 3921:1985 [13]. In testing the thermal comfort of bricks, only model of masonry unit consists of $30 \%$ replacement of ceramic waste was calibrated in order to measure the temperature of interior and exterior of building model and compared to control masonry unit. The purpose was to establish the influence of ceramic waste contents which was achieved the optimum crushing strength value. Hopefully, the outcome of the investigation conducted was able to propose the ceramic waste as sustainable materials in minimizing the wastage from rejected to valuable materials.

\subsection{METHODOLOGY}

Four (4) different percentages of ceramic waste replacement were prepared with 10\% (CW10), 20\% (CW20) and 30\% (CW30) from the total weight of sand. It was also included the control mortar bricks without ceramic waste (CWO). The purpose of introducing different percentages of ceramic waste contents was to investigate the effect of ceramic waste replacement to crushing strength, water absorption, compressive strength of masonry units and thermal comfort followed as stipulated in MS
2281:2010, MS 327-Part 3: 1997 and ASTM C1314-16. The following outline describes the procedure performed in preparing the ceramic waste and mortar bricks.

\subsection{Preparation of Ceramic Waste}

The ceramic waste was collected from Guocera Industries Sdn. Bhd. which was located in Kluang, Johor, Malaysia. The sacks of ceramic waste collected was cleaned and crushed using tap water and Los Angeles abrasion machine, respectively. Then, it was sieved to obtain the size of $5 \mathrm{~mm}$ which was the same size of sand used in this present study.

\subsection{Preparation of Mortar Bricks}

The size of mortar brick specimens used was $215 \mathrm{~mm} x$ $102.5 \mathrm{~mm} \times 65 \mathrm{~mm}$ which is classified as cuboid bricks (ASTM C1314-16) with proportion of 1:6 which is ratio of Portland cement to sand. The wood mould was assembled as shown in

Figure 1 with thickness of $4 \mathrm{~mm}$. Then, the mix were poured into the mortar bricks mould and pressed using low pressure hydraulic hand pump. After the mix hardened for 24 hours, the hardened specimens were cured in room temperature prior to testing.

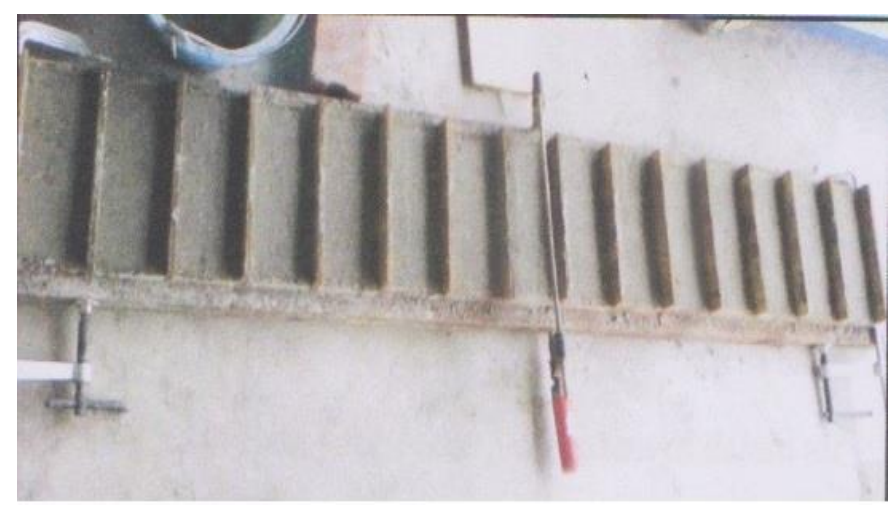

Figure 1 Wood mould used to cast brick specimens

\subsection{Mix Proportion of Materials}

Table 1 shows the mix proportion used of cement, sand and ceramic waste including the total of specimens prepared subjected to crushing strength, water absorption, compressive strength of masonry prism and thermal comfort. Total of specimens required for all testing were 184 specimens of mortar bricks. 
Table 1 Proportion of sand and ceramic waste with total number of specimens prepared

\begin{tabular}{|c|c|c|c|c|c|c|c|}
\hline \multirow{3}{*}{ Symbol } & \multirow{3}{*}{$\begin{array}{l}\text { Fine } \\
\text { Sand } \\
(\%)\end{array}$} & \multirow{3}{*}{$\begin{array}{c}\text { Ceramic } \\
\text { Waste } \\
(\%)\end{array}$} & \multicolumn{5}{|c|}{ Total Specimen } \\
\hline & & & \multicolumn{2}{|c|}{ Crushing Strength } & \multirow{2}{*}{$\begin{array}{c}\begin{array}{c}\text { Water } \\
\text { Absorption }\end{array} \\
28 \\
\text { days } \\
\end{array}$} & \multirow{2}{*}{$\begin{array}{c}\text { Compressive Strength } \\
\text { Masonry Prism }\end{array}$} & \multirow{2}{*}{$\begin{array}{c}\text { Thermal } \\
\text { Comfort } \\
28 \\
\text { days }\end{array}$} \\
\hline & & & $\begin{array}{c}7 \\
\text { days }\end{array}$ & $\begin{array}{c}28 \\
\text { days }\end{array}$ & & & \\
\hline CWO & 100 & 0 & 3 & 3 & 5 & 15 & 40 \\
\hline CW10 & 90 & 10 & 3 & 3 & 5 & 15 & - \\
\hline CW20 & 80 & 20 & 3 & 3 & 5 & 15 & - \\
\hline CW30 & 70 & 30 & 3 & 3 & 5 & 15 & 40 \\
\hline
\end{tabular}

\subsection{Crushing Strength of Mortar Bricks}

MS 327-Part 3:1997 outlined the crushing strength was calculated with total maximum load, $W$ divided with average of the gross areas, $A$. The test of crushing strength or also known as compressive strength was conducted at the age of 7 and 28 days of curing using compression machine as shown in Figure 2.

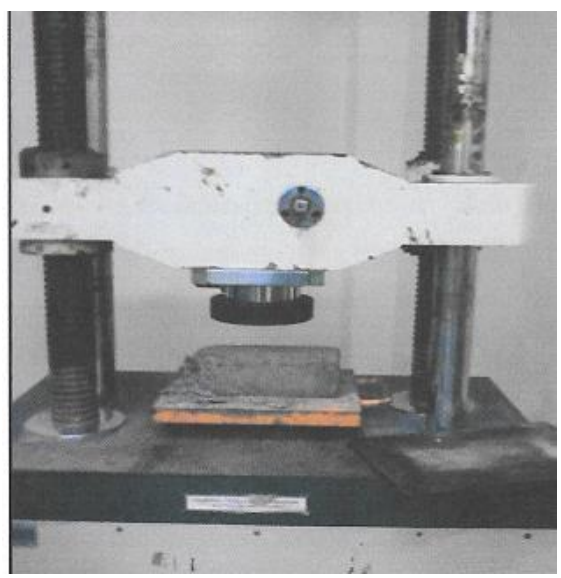

Figure 2 The mortar bricks was crushed to obtain crushing strength

\subsection{Water Absorption of Mortar Bricks}

MS 327-Part 3:1997 stated the specimens of mortar bricks was dried at six (6) hours and weighed as specimen's weight before immersion $\left(W_{d}\right)$. Then, the specimens was immersed in distilled water and boiled for two (2) hours before it was remained immersed in water for twenty (20) hours. Eventually, the mortar bricks surface was wiped using the damp cloths and weighed as specimens after immersion $\left(W_{w}\right)$. The water absorption was calculated based on Equation 1;

$$
\text { Water absorption }=\mathrm{W}_{\mathrm{d}}-\mathrm{W}_{\mathrm{w}} \quad(\text { Equation 1) }
$$

\subsection{Compressive Strength of Masonry Prism}

In the prism test method, five (5) specimens of mortar bricks was assembled as masonry unit and tested their compressive strength. The prism of mortar bricks was stacked altogether and grouted as shown in Figure 3 was used the mixture of cement and sand with proportion of 1:3. After grouting, the prism was cured in room temperature for 48 hours prior to testing. During the test, the capping plate with dimension of $400 \mathrm{~mm}$ and $194 \mathrm{~mm}$ was placed on the top and bottom of prism set as shown in Figure 4 in accordance with ASTM C1314-16.

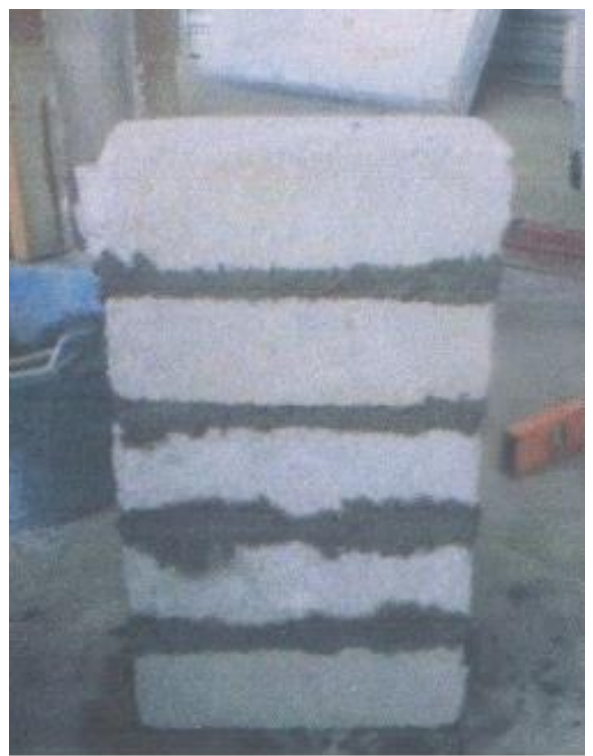

Figure 3 The arrangement of bricks made on one set of masonry prism 


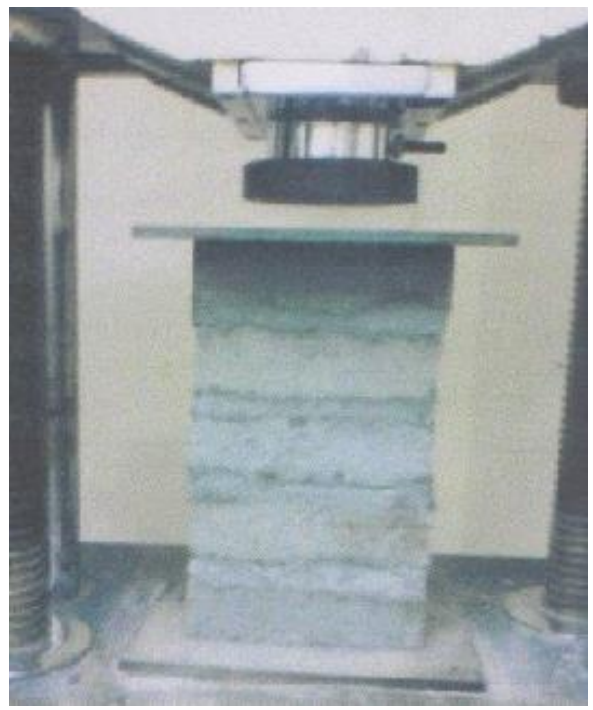

Figure 4 The arrangement of capping plate prior to testing

\subsection{Thermal Comfort of Masonry Units}

The temperature of interior and exterior in model prototype was taken for 14 days using Rotronic Instrument. The readings were recorded at three (3) different durations comprises of morning, afternoon and night which was measured at $7 \mathrm{am}, 12 \mathrm{pm}$ and $5 \mathrm{pm}$. The interior and exterior temperatures were measured by constructing the model prototype consists of 40 specimens of mortar bricks for control and same model for ceramic mortar bricks as shown in Figure 5.

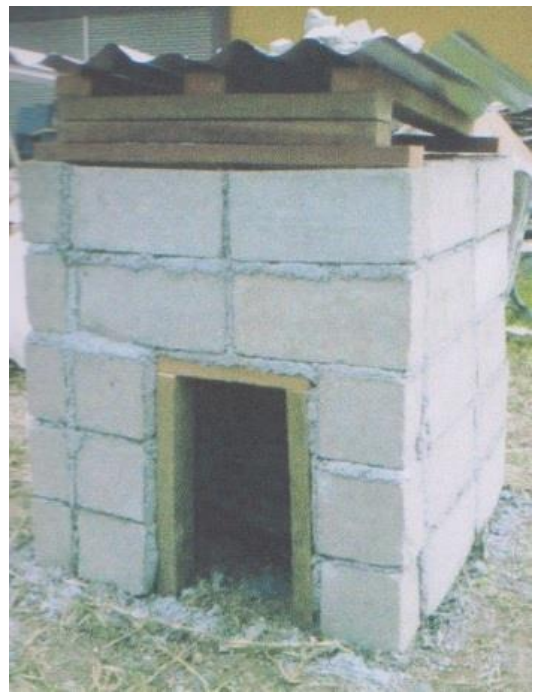

Figure 5 Model prototype of masonry unit consist of mortar bricks

\subsection{RESULTS AND DISCUSSION}

The section describes the result obtained from the laboratory test with the discussion based on the figure illustration and previous studies.

\subsection{Crushing Strength of Mortar Bricks}

The results explained the crushing strength was increased with the increase of ceramic waste contents. The mortar bricks contains CW10, CW20 and CW30 indicated high increment of crushing strength at about $23 \%, 37 \%$ and $46 \%$ respectively corresponding to the control mortar bricks as shown in Figure 6. Previously, the similar pattern was observed that inclusion of ceramic waste in clay bricks contribute the high crushing strength (Nirmala and Viruthagiri 2015, Ali et al. 2016, Silva et al. 2017). While, Hanifi 2007 [14] and Jiménez et al. 2013 [7] found the increment of crushing strength was at about $14 \%$ in mortar bricks and $40 \%$ in mortar specimens, respectively containing ceramic waste at the age of 28 days curing. Similar pattern was also reported in Fernando and Said 2010 [15] which was replaced the ceramic waste to aggregate in concrete specimens with increment of $13 \%$. However the study of Abdul Rahman et al. 2015 [16] reported the low increment at about $2 \%$ of crushing strength between mortar specimens with and without ceramic waste.

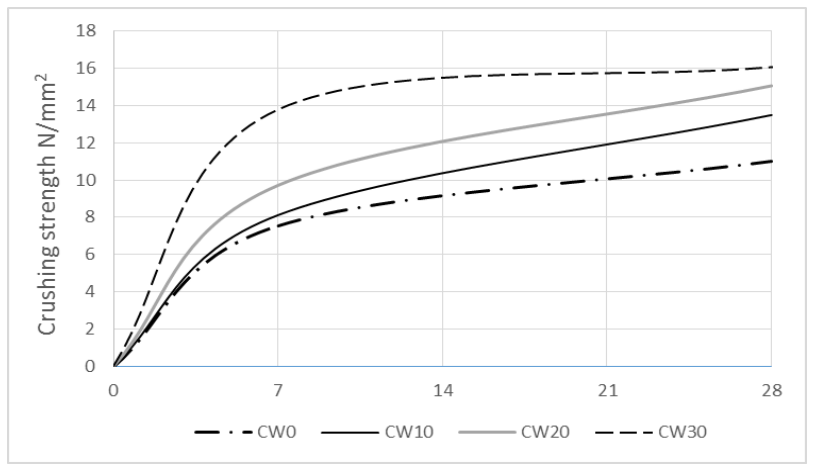

Figure 6 Effect of ceramic waste inclusion to the crushing strength of mortar bricks at the age of 7 and 28 days of curing

\subsection{Water Absorption of Mortar Bricks}

At the age of 28 days after curing, the ceramic mortar bricks of CW2O and CW30 indicated low water absorption with $3.6 \%$ and $4.2 \%$, respectively with respect to control mortar bricks without ceramic waste as illustrated in

Figure 7. However, specimens of CW10 denoted high water absorption at $7.3 \%$ while control specimens was $6.4 \%$. Clearly seen that the high contents of ceramic waste decreased the water absorption of ceramic mortar bricks. 


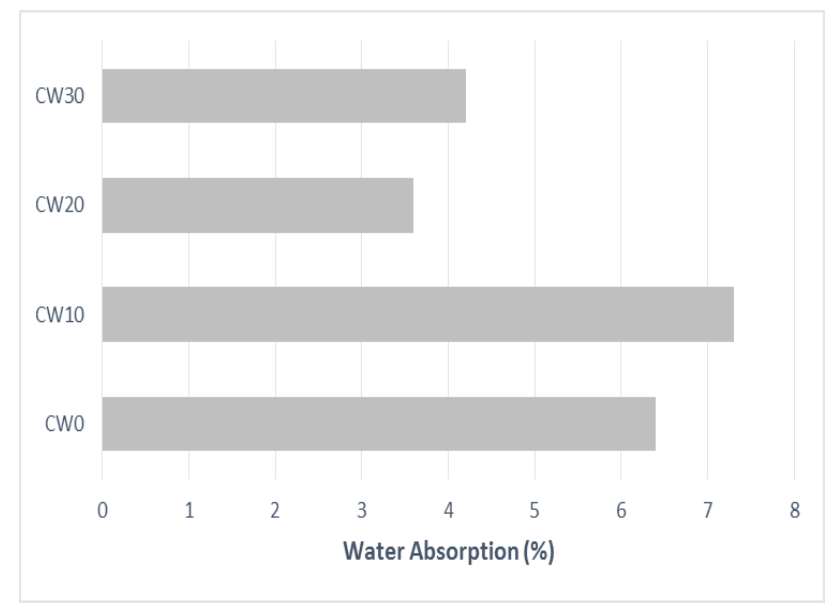

Figure 7 Water absorption of mortar bricks containing with and without ceramic waste

Contradictory from the previous outcome in Ghafour et al. 2010 [17] which was recorded high water absorption in fired clay bricks containing ceramic sludge. Similar result was observed in ceramic concrete specimens which was recorded high water absorption compared to control specimens without ceramic waste (Sudarsana et al. 2013 [18]). High water absorption can be due to physical conditions of ceramic waste which was consists of crystalline structure on the surface. However, this result obtained in this present study agree with study of Dina et al. 2013 [19] and Niyazi 2015 [20] which was concluded the increment of ceramic waste contents decreased the water absorption of mortar bricks. Low water absorption was confirmed with the evidence obtained in micrograph image which was showed the microstructure of ceramic mortar brick specimens presented the sintering heat treatment (Nirmala and Viruthagiri, 2015). In this process, the big pores in the mortar bricks containing ceramic waste was removed. Therefore, minimal amount of water was able to penetrate into the internal structure of mortar bricks containing ceramic waste.

\subsection{Compressive Strength of Masonry Prism}

The increased of ceramic waste contents shows the huge increment of compressive strength of masonry units. It can be up to $200 \%$ of compressive strength with respect to control mortar brick as shown in Figure 8. This outcome confirms the potential of ceramic waste as the replacement to fine aggregate. Conversely, on the previous study (Ghafour et al. 2010) concluded the replacement of ceramic sludge in clay bricks was not contributed high compressive strength. The decrement of compressive strength recorded was more than $10 \%$. However, similar pattern was observed in masonry mortar units containing more than $50 \%$ ceramic waste with increment up to $50 \%$ compressive strength (Fernando et al. 2017).

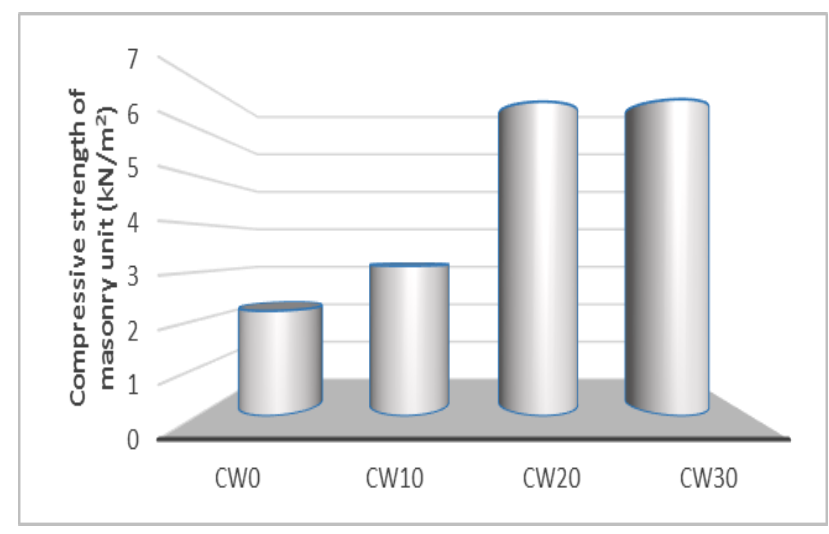

Figure 8 Compressive strength of masonry units containing with and without ceramic waste at the age of 28 days after curing

\subsection{Thermal Comfort of Masonry Units}

The outdoor temperature of the masonry units containing ceramic waste did not show any significant values due to similar temperature recorded compared to control masonry units. While, the ceramic mortar bricks indicated the low temperature of interior as shown in Figure 9. The fluctuations temperature was detected in unit model of control and ceramic masonry unit during morning and afternoon within 14 days. The lowest temperature was recorded in the evening for both units prototype model. The range of temperature recorded in mortar and control masonry units was between $22^{\circ} \mathrm{C}$ and $36^{\circ} \mathrm{C}$ and from $23^{\circ} \mathrm{C}$ to $38^{\circ} \mathrm{C}$, respectively. While the unit model of ceramic mortar bricks indicated lowest temperature in the evening with range between $22^{\circ} \mathrm{C}$ and $28^{\circ} \mathrm{C}$ than control unit. For Malaysia climate, Department of Standards Malaysia, 2007 [21] recommended the range of indoor temperature was between $23^{\circ} \mathrm{C}$ and $26^{\circ} \mathrm{C}$. Study of Sabarinah and Steven, 2007 [22] proposed the comfort temperature of all building should be below $28.6^{\circ} \mathrm{C}$. Therefore, the prototype model of ceramic masonry units responded better thermal comfort than control mortar bricks. 


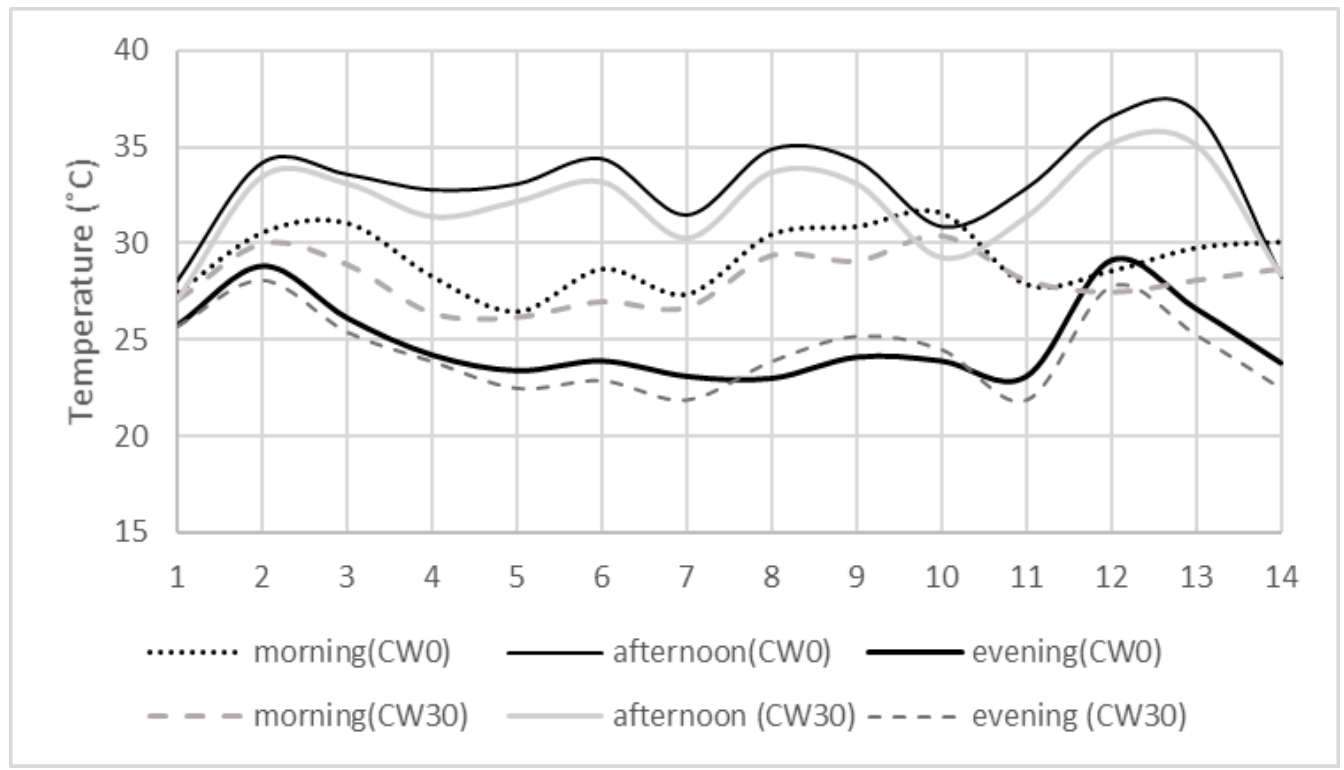

Figure 9 Measurement of interior temperatures in prototype model of control (CWO) and ceramic masonry units (CW30) within fourteen days

\subsection{CONCLUSION}

The incorporation of ceramic waste in mortar bricks as sand replacement with $10 \%, 20 \%$ and $30 \%$ increased the crushing strength with increment of $23 \%, 37 \%$ and $46 \%$ with the low water absorption corresponding to mortar bricks without ceramic waste. While, compressive strength of masonry units was increased up to $200 \%$. Subsequently, the thermal comfort in masonry units of ceramic mortar bricks recorded the low interior temperature. Therefore, the replacement of ceramic waste to fine aggregate proven significantly enhance the brick properties and their performance performed the potential in replacing fine aggregate in brick productions.

\section{References}

[1] Sh. K. Amin, H. A. Sibak, S. A. El-Sherbiny, M. F. Abadir. 2016. An Overview of Ceramic Wastes Management in Construction. International Journal of Applied Engineering Research. 11 (4): 2680-2685,

[2] Alonso-Santurde, R., A. Coz, J.R. Viguri, A. Andrés. 2012. Recycling of Foundry By-products in the Ceramic Industry: Green and Core Sand in Clay Bricks. Journal of Construction and Building Material. 7: 96-106. http://doi.org/10.1016/j.conbuildmat.2011.08.022.

[3] G. Nirmala, G. Viruthagiri. 2015. A View of Microstructure with Technological Behavior of Waste Incorporated Ceramic Bricks. Spectrochimica Acta Part A: Molecular and Biomolecular Spectroscopy. 135: 76-80. http://doi.org/10.1016/j.saa.2014.06.150.

[4] Tereza Kulovaná, Eva Vejmelková, Jaroslav Pokorný, Jamal Akhter Siddique, Martin Keppert, Pavla Rovnaníková, Michal Ondráček, Zbyněk Keršner, Robert Černý. 2015. Engineering Properties of Composite Materials Containing Waste Ceramic Dust from Advanced Hollow Brick Production as a Partial Replacement of
Portland Cement. Journal of Building Physics. 40(1): 17-34. https://doi.org/10.1177/1744259115597228.

[5] N. Ali, K. Y. Yaacob, S. Shahidan, and S. R. Abdullah. 2016. Investigation of Compressed Earth Brick Containing Ceramic Waste. ARPN J. Eng. Appl. Sci. 11 (8): 5459-5462.

[6] Silva, Vamberto Monteiro da, Góis, Luciano Costa, Duarte, João Batista, Silva, Jaquelígia Brito da, \& Acchar, Wilson. 2014. Incorporation of Ceramic Waste into Binary and Ternary Soil-cement Formulations for the Production of Solid Bricks. Materials Research. 17(2): 326-331. http://dx.doi.org/10.1590/S1516-14392014005000014.

[7] J. R. Jiménez, J. Ayuso, M. López, J. M. Fernández, J. de Brito. 2013. Use of Fine Recycled Aggregates from Ceramic Waste in Masonry Mortar Manufacturing. Construction and Building Materials. 40: 679-690. http://doi.org/10.1016/j.conbuildmat.2012.11.036.

[8] Fernando López Gayarre, Íñigo López Boadella, Carlos López-Colina Pérez, Miguel Serrano López, Alberto Domingo Cabo. 2017. Influence of the Ceramic Recycled Agreggates in the Masonry Mortars Properties. Construction and Building Materials. 132: 457-461. DOI: 10.1016/j.conbuildmat.2016.12.021.

[9] Zhang Haiying, Zhao Youcai, Qi Jingyu. 2011. Utilization of Municipal Solid Waste Incineration (MSWI) Fly Ash in Ceramic Brick: Product Characterization and Environmental Toxicity. Waste Management. 31(2): 331341. http://doi.org/10.1016/j.wasman.2010.10.017.

[10] 1997. Specification for Refractory Bricks Part 3: Physical Tests. First Revision. MS 327:Part 3: 1997, Malaysia Standard.

[11] 2016. Standard Test Method for Compressive Strength of Masonry Prisms, ASTM C1314 - 16, ASTM International, Inc.

[12] 2010. Clay and Calcium Silicate Bricks of Special Shapes and Sizes-Recommendations, MS 2281:2010, Malaysia Standard.

[13] 2015. Specification for Masonry Units. Clay Masonry Units. BS EN 771-1:2011+A1:2015, British Standard.

[14] Hanifi Binici. 2007. Effect of Crushed Ceramic and Basaltic Pumice as Fine Aggregates on Concrete Mortars Properties. Construction and Building Materials. 21(6): 1191-1197.

http://doi.org/10.1016/j.conbuildmat.2006.06.002

[15] Fernando Pacheco-Torgal and Said Jalali. 2011. Compressive Strength and Durability Properties of Ceramic Wastes Based Concrete. Materials and 
Structures, Materials and Structures. 44(1): 155-167. http://doi:10.1617/s1 1527-010-9616-6.

[16] Abdul Rahman Mohd Sam, Mostafa Samadi, Mohd Warid Hussin, Han Seung Lee, Mohamed A. Ismail, Nor Hasanah Abdul Shukor Lim, Nur Farhayu Ariffin, Nur Hafizah A. Khalid, Mund Zaimi Abd. Majid, Jahangir Mirza. 2015. Incorporation of Homogenous Ceramic Tile Waste to Enhance Mechanical Properties of Mortar. 77(16): Research Advances in Sustainable Structure, Material and Construction. Jurnal Teknologi. 21-25. http://dx.doi.org/10.11113/jt.v77.6389.

[17] N. G. Abd El-Ghafour. 2010. Making Green Building Units By Using Some Wastes of Ceramic Industry. Proceedings of the Tenth International Conference for Enhanced Building Operations, Kuwait, October 26-28.

[18] Sudarsana Rao hunchate, Giridhar Valikala, Vaishali. G. Ghorpade. 2013. Influence of Water Absorption of the Ceramic Aggregate on Strength Properties of Ceramic Aggregate Concrete. International Journal of Innovative Research in Science, Engineering and Technology. 2(11).

[18] Dina, M. Sadek, Walid, S. El-Sayed, Ashraf, M. A. Heniegal, Ayman, S. Mohamed. 2013. Utilization of Solid Waste in
Cement Bricks for Environmental Beneficial. International Journal of Engineering Tome XI, Tome XI, Fascicule. 3:. 187194.

[19] Niyazi Ugur Kockal. 2015. Behavior of Mortar Produced with Construction Wastes Exposed to Different Treatments. Indian Journal of Engineering \& Material Sciences. 22: 203214.

[20] Mostafa Samadi, Mohd Warid Hussin, Han Seung Lee, Abdul Rahman Mohd Sam, Mohamed A. Ismail, Nor Hasanah Abdul Shukor Lim, Nur Farhayu Ariffin, Nur Hafizah A. Khalid. 2015. Properties of Mortar Containing Ceramic Powder Waste as Cement Replacement. Jurnal Teknologi. 93-97. http://dx.doi.org/10.11113/jt.v77.6315.

[21] 2007. Code of Practice on Energy Efficiency and Use of Renewable Energy, Malaysia, MS1525:2007, Department of Standards Malaysia.

[22] Sabarinah, S., \& Steven, V. S. 2007. The Performance of a Partially Air Conditioned Apartment Building in Kuala Lumpur. Proceeding in the 24th International Conference on Passive and Low Energy Architecture, Singapore. 608614. 